\title{
UPAYA MENINGKATKAN PROSES DAN HASIL BELAJAR GEOGRAFI MELALUI MODEL PEMBELAJARAN COOPERATIVE LEARNING TIPE STAD PADA SISWA KELAS XI IPS SMA NEGERI 1 BANGUNTAPAN
}

\author{
Suyatinah \\ SMA Negeri 1 Banguntapan, Bantul, DI Yogyakarta \\ suyatinah.ninok@mail.com
}

\begin{abstract}
Abstrak: Penelitian ini bertujuan untuk mengetahui penerapan dan pengaruh pembelajaran tipe STAD terhadap proses dan hasil pembelajaran geografi di kelas XI IPS 3 SMA Negeri 1 Banguntapan tahun ajaran 2018/2019. Penelitian ini termasuk penelitian tindakan kelas. Subjek penelitian adalah 36 siswa kelas XI IPS 3 SMA Negeri 1 Banguntapan. Tahapan penelitian meliputi perencanaan, implementasi, observasi dan refleksi, yang dilakukan dalam 2 siklus. Pembelajaran geografi dengan tipe STAD dilaksanakan dengan mengelompokkan siswa dalam 6 kelompok heterogen untuk membahas tugas yang diberikan kepada masing-masing kelompok. Hasil diskusi kelompok dicatat kemudian dipresentasikan. Pada akhir kegiatan, siswa diberikan kuis individu, kemudian nilainya digabungkan menjadi nilai kelompok. Kelompok yang mendapat nilai tertinggi akan mendapatkan hadiah. Kerjasama siswa terjadi dalam pembelajaran menggunakan STAD. Adanya proses tutor sebaya ini meningkatkan proses pembelajaran siswa kelas XI IPS 3 dari 91,30\% pada siklus I, menjadi 96,00\% pada siklus II. Tipe STAD juga dapat meningkatkan hasil belajar geografi, hal ini ditunjukan dengan meningkatnya nilai kuis untuk masing-masing kelompok dari 5,68 pada siklus I menjadi 8,27 pada siklus II, juga terjadi peningkatan pada pengajuan Studi awalnya $71,92 \%$ pada siklus I dan $82,12 \%$. dalam siklus II.
\end{abstract}

Kata kunci: motivasi belajar, pembelajaran kooperatif, STAD

\section{IMPROVING THE PROCESS AND LEARNING OUTCOMES OF GEOGRAPHY THROUGH COOPERATIVE LEARNING MODEL STAD TYPE FOR GRADE XI OF SOCIAL STUDENTS IN SMA NEGERI 1 BANGUNTAPAN}

\begin{abstract}
The purpose of research is to determine the implementation of our Cooperative Learning model of the STAD type in the learning Geography and to know influence this STAD type to process and results of geography learning in the class XI IPS 3 SMA Negeri 1 Banguntapan school year 2018/2019. The type of research used is classroom action research. The subject of research is class student XI IPS 3 SMA Negeri 1 Banguntapan Bantul school year 2018/2019 amounted to 26 people. The research measures include planning, implementation, observation and reflection, implemented in 2 cycles. The learning of geography with STAD type is implemented by dividing students in 6 groups heterogeneous to discuss the tasks given to each group. Results of group discussions are noted for group presentation purposes. At the end of the requestor are given an individually performed quiz, the value is combined into a group score. The group that gets the highest points increase will earn rewards. The training STAD type can to collaborate in the learning process, there is the process of peer tutor, this enhances the learning process of students Klas XI IPS 3 from $91.30 \%$ (pertinent) in cycle I, to $96.00 \%$ (pertinent) in cycle II. This type can also improve the results of geography learning, evidenced by the increase of quiz result group points results from 5.68 points in cycle I to 8.27 points in cycle II, also occurs improvement of the submission Study originally $71.92 \%$ in cycle I and $82.12 \%$ in cycle II.
\end{abstract}

Keywords: motivation to learn, cooperative learning, STAD.

\section{PENDAHULUAN}

Upaya pemerintah untuk meningkatkan kualitas pendidikan di Indonesia dijelaskan dalam pasal 19 ayat 1 Peraturan Pemerintah Nomor 19 Tahun 2005 tentang Standar Nasional Pendidikan, menyatakan bahwa proses pendidikan pada satuan pendidikan diselenggarakan secara interaktif, inspiratif, menyenangkan, menantang, memotivasi peserta didik untuk berpartisipasi aktif, serta memberi ruang yang cukup bagi prakarsa, kreatifitas, dan kemandirian sesuai dengan bakat, minat, dan perkembangan fisik serta psikologis peserta didik. Hal ini menunjukkan adanya paradigma proses pembelajaran yang selama ini berpusat pada guru (teacher oriented) ke arah proses pembelajaran yang berpusat pada siswa (student oriented). 
Geografi merupakan ilmu yang mempelajari gejala alam (litosfer, pedosfer, hidrosfer, atmosfer, biosfer) dan manusia, serta interaksi antara keduanya. Obyek kajian geografi adalah hal- hal yang nyata dipermukaan bumi, seharusnya dapat dibelajarkan dengan berbagai metode aktif seperti CTL/ Contextual Teaching and Learning, Inquiri, Problem Solving, Cooperatif Learning, dll sesuai dengan tuntutan Kurikulum 2013. Namun pada kenyataannya metode ceramah dan variasinya masih sulit ditinggalkan, sehingga pembelajaran geografi lebih dikenal sebagai materi hafalan. Siswa cenderung kurang menyukai mata pelajaran ini, dampaknya terlihat pada kurang maksimalnya hasil belajar. Kondisi seperti itu terjadi pula di Kelas XI IPS 3 SMA Negeri 1 Banguntapan. Pada semester ganjil tahun pelajaran 2018/ 2019 diperoleh data bahwa rata- rata hasil penilaian harian, penilaian tengah semester dan penilaian akhir semester tidak mencapai KKM yang ditetapkan, yaitu 76. Untuk memperbaiki kondisi tersebut, akan diterapkan model pembelajaran Kooperatif tipe STAD (Student Teams - Achievment Divission). Model ini menekankan pembagian siswa secara heterogen dalam kelompoknya, sehingga diharapkan akan terjadi tutor teman sebaya. Proses belajar yang lebih aktif diharapkan mampu meningkatkan hasil belajar.

\section{Proses Belajar}

Merupakan interaksi semua komponen atau unsur yang terdapat dalam proses belajar mengajar, yang meliputi tujuan instruksional, materi pelajaran, metode mengajar, media pembelajaran/ alat peraga, dan evaluasi. Berbagai komponen tersebut saling berhubungan (interdependensi) dalam ikatan untuk mencapai tujuan.

Hasil belajar merupakan hasil yang dicapai oleh seseorang dalam usaha belajar sebagaimana yang dinyatakan dalam raport. (Poerwanto dalam Jamaliah, 2010 : 63).

Proses belajar dan hasil belajar atau prestasi belajar merupakan dua hal yang tidak dapat dipisahkan, karena kegiatan belajar merupakan proses dan prestasi merupakan hasil dari proses belajar. Agar dapat mencapai prestasi belajar yang optimal, proses belajar harus berlangsung secara efektif.
Model Cooperative Learning Tipe STAD (Student Teams - Achievment Divission).

Model Pembelajaran yang dipilih dalam Penelitian Tindakan Kelas ini Cooperative Learning tipe adalah STAD (Student TeamsAchievement Division) dengan langkahlangkahnya adalah sebagai berikut : a). Membentuk kelompok siswa dengan anggota 4 orang secara heterogen (campuran menurut prestasi, agama, jenis kelamin, dll), b). Guru menyampaikan materi pokok pembelajaran, c). Guru memberi tugas kepada kelompok untuk dikerjakan secara bersama, selanjutnya hasil diskusi kelompok disampaikan kepada semua siswa melalui presentasi, d). Guru memberi kuis/ pertanyaan kepada seluruh siswa yang dikerjakan secara individu, dalam menjawab tidak saling membantu, e). Skor kuis para siswa dibandingkan dengan rata- rata pencapaian siswa sebelumnya, Poin itu selanjutnya dijumlahkan untuk memperoleh skor tim. Masing-masing tim akan diberikan poin peningkatan/penurunan poin. Tim yang berhasil memenuhi kriteria tertentu/ memperoleh poin tertinggi akan diberikan penghargaan/ reward. Pada tipe $S T A D$ ini tanggung jawab individual sangat diperlukan demi keberhasilan kelompok (Robert E. Slavin, 2009 : 11).

\section{METODE PENELITIAN}

\section{Jenis Penelitian}

Penelitian ini merupakan Penelitian Tindakan Kelas.

\section{Waktu dan Tempat Penelitian}

Penelitian dilaksanakan 4 (empat) bulan mulai bulan Januari 2019 sampai dengan bulan April 2019, yang bertempat di SMA Negeri 1 Banguntapan Bantul yang ber alamat di Ngentak, Baturetno, Banguntapan, Bantul.

\section{Subjek Penelitian}

Subjek penelitian adalah siswa klas XI IPS 3 SMA Negeri 1 Banguntapan Bantul tahun pelajaran 2018/ 2019 yang berjumlah 26 siswa, terdiri 11 siswa laki- laki dan 15 siswa perempuan.

\section{Prosedur Penelitian}

Setiap siklus dalam kegiatan Penelitian Tindakan Kelas yang dilaksanakan meliputi 4 tahap, yaitu perencanaan, pelaksanaan, observasi, dan refleksi. Pada tahap perencanaan kegiatan yang dilakukan meliputi penyusunan : RPP, instrumen observasi pengamatan proses belajar dan mengajar, 
instrumen penilaian, LKS, dll. Pada tahap pelaksanaan, guru melaksanakan kegiatan pembelajaran. Aktivitas mengajar guru dan aktivitas belajar siswa diobservasi. Hasil pengamatan digunakan sebagai refleksi pada siklus berikutnya. Jika sudah ada peningkatan proses belajar dan hasil belajar dari siklus I ke siklus II, maka siklus dihentikan.

\section{Data, Intrumen, dan Teknik Pengumpulan Data} Tehnik pengumpulan data dalam penelitian ini meliputi :

1. Data pra siklus terkait motivasi belajar siswa diperoleh dari angket yang diisikan siswa pada instrumen angket, sedangkan data terkait hasil belajar diperoleh dari dokumen leger.

2. Data terkait proses belajar siswa dan proses mengajar guru saat pelaksanaan tindakan diperoleh melalui observasi dengan menggunakan lembar observasi dan dokumentasi foto.

3. Data terkait hasil belajar diperoleh dengan pemberian kuis yang diberikan pada akhir kegiatan pembelajaran, sedangkan penilaian harian diberikan pada setiap akhir siklus, dengan menggunakan instrumen kuis dan penilaian harian.

\section{Teknik Analisis Data dan Indikator Keberhasilan}

Teknik analisa data pada penelitian ini meliputi: 1) Teknik analisa diskriptif kualitatif digunakan untuk mendiskripsikan kondisi pra siklus terkait motivasi belajar siswa, 2) Teknik analisa kuantitatif digunakan untuk menghitung: a) Prosentase proses belajar siswa dari lembar obsevasi, dimana siswa yang on task (terlibat aktif dalam kegiatan belajar) dan siswa yang off task (tidak aktif dalam kegiatan belajar pada setiap siklus/ setiap periode tertentu, bahwa on task $>80 \%$ tergolong adekuat dan $>90 \%$ tergolong bagus (Muij \& Reynolds, 2008: 385). b) Menghitung peningkatan poin kelompok yang diperoleh dari penilaian kuis. Peningkatan nilai tertinggi pada kelompok digunakan dasar untuk memberi reward. Reward ini diberikan untuk lebih memotivasi kelompok lainnya untuk mencapai proses belajar yang maksimal, c) menghitung hasil belajar siswa dari hasil penilaian harian, dengan mengacu pada KKM yang ditetapkan yaitu 76, siswa yang sudah melampaui KKM digolongkan tuntas, dan siswa yang belum mencapai KKM tergolong belum tuntas.

\section{HASIL PENELITIAN \\ Kondisi Pra Siklus}

Kondisi pra siklus yang mendukung motivasi belajar geografi antara lain :

a. 95,5 \% siswa kelas XI IPS 3 SMA N 1 Bangutapan Tahun Ajaran 2018/ 2019 senang belajar geografi dengan alasan materi yang dipelajari merupakan materi yang kontekstual.

b. Semua siswa memiliki buku latihan soal

c. Siswa memiliki buku paket yang dipinjam dari sekolah.

Kondisi yang kurang mendukung proses belajar geografi berjalan dengan baik antara lain :

a. $45 \%$ siswa menyatakan frekwensi belajarnya tidak ajeg,

b. $86 \%$ siswa menyatakan metode mengajar guru kurang bervariasi, cenderung metode ceramah sehingga proses pembelajaran berpusat pada guru,

c. Hasil dari dua kali penilaian harian, penilaian tengah semester dan penilaian akhir semester rata- rata belum mencapai KKM (76).

\section{Hasil Penelitian Siklus I}

Siklus I terdiri dari 3 pertemuan, yaitu pertemuan ke-1 dan ke-2 merupakan kegiatan pembelajaran dan pertemuan ke-3 digunakan untuk penilaian harian.

\section{Pertemuan ke-1, Siklus I}

Pada setiap pertemuan terdiri dari 4 tahap, yaitu perencanaan, pelaksanaan, observasi dan refleksi.

1) Tahap perencanaan

Tahap ini dilaksanakan pada bulan Januari berupa penyusunan beberapa instrumen penelitian, seperti : RPP, Lembar Kerja Siswa (LKS), bahan ajar, media pembelajaran, lembar observasi/ pengamatan proses belajar siswa dan proses mengajar guru, instrumen angket motivasi belajar siswa, instrumen penilaian, meliputi penilaian kuis dan penilaian harian, menyusun kelompok belajar.

\section{2) Tahap pelaksanaan}

Pertemuan ke-1 dilaksanakan pada hari Rabu, tanggal 27 Pebruari 2019, jam ke 5-6 dengan materi Memahami Budaya Indonesia. Tahap pelaksanaan berjalan sebagai berikut: Kegiatan Pendahuluan (10 menit): guru mengawali pembelajaran dengan salam pembuka dilanjutkan presensi siswa, guru memberikan apersepsi, guru menyampaikan 
tujuan pembelajaran dan guru menjelaskan model pembelajaran yang akan digunakan yaitu Student Team Achievment Division dimana siswa dibagi dalam kelompok secara heterogen. Kegiatan Inti (70 menit) : guru menjelaskan materi secara garis besar, guru membagi tugas kelompok, meliputi kelompok 1 membahas materi : konsep budaya, konsep budaya lokal dan budaya nasional, kelompok 2 membahas materi: Unsur-unsur kebudayaan, kelompok 3 membahas materi: Bentuk-bentuk kebudayaan, Kelompok 4 membahas materi : Pengaruh letak geografis terhadap keragaman budaya nasional, kelompok 5 membahas materi: Pengaruh posisi strategis terhadap keragaman budaya nasional, kelompok 6 membahas materi: Pengaruh ekologis terhadap keragaman budaya nasional. Siswa dalam kelompoknya berdiskusi sesuai dengan materi bahasannya masing-masing. Salah satu kelompok mempresentasikan hasil diskusi kelompoknya, sedangkan kelompok lain bertanya/ menanggapi. Guru memantau pelaksanaan diskusi dan presentasi. Kegiatan Penutup (10 menit): guru bersama siswa membuat kesimpulan dan refleksi pembelajaran, guru memberikan kuis sebagai ukuran penguasaan materi oleh siswa secara individu. Poin dari masing- masing anggota kelompok akan dijumlahkan menjadi nilai tim/nilai kelompok. Guru memberikan tugas untuk pertemuan yang akan datang.

3) Tahap Observasi

Pada tahap ini dilakukan pengamatan terhadap :

a) proses belajar siswa, diperoleh data bahwa 3 siswa tidak masuk, sehingga ada 23 siswa yang masuk, dan 2 diantaranya tidak aktif mengikuti proses belajar dalam kelompoknya, sehingga tingkat keaktifan siswa sebesar $91,3 \%$, tergolong bagus/ aktif.

b) Proses mengajar guru dengan menggunakan instrumen observasi, diperoleh skor 75, tergolong baik, namun ada sedikit kekurangan pada tahap pendahuluan, guru lupa menyampaikan tujuan pembelajaran, pembagian kelompok dan penyampaian tugas kelompok kurang cepat.

c) Hasil Belajar Siswa

Data penilaian kuis pada pertemuan ke- 1 , siklus I terjadi penurunan poin rata- rata $-0,59$, kelompok 3 memperoleh peningkatan reward karena mencapai peningkatan poin terbesar, seperti dipaparkan dalam tabel berikut.
Tabel 1. Peningkatan poin kelompok Pertemuan ke-1 Siklus I

\begin{tabular}{cccc}
\hline \multirow{4}{*}{ Kelompok } & $\begin{array}{c}\text { Nilai } \\
\text { awal }\end{array}$ & $\begin{array}{c}\text { Nilai } \\
\text { kuis }\end{array}$ & $\begin{array}{c}\text { Peningkatan poir } \\
\text { kelompok }\end{array}$ \\
\hline 1. & 74,25 & 57,5 & $-16,75$ \\
2. & 69,6 & 77,5 & 7,9 \\
3. & 68 & 82,5 & 14,5 \\
4. & 69 & 50 & -19 \\
5. & 67,2 & 70 & 2,8 \\
6. & 68 & 75 & 7 \\
\hline \multicolumn{4}{r}{ Rata- rata peningkatan poin } \\
\hline
\end{tabular}

4) Tahap refleksi

Kekurangan yang ditemukan pada pertemuan ke-1 dipergunakan sebagai masukan untuk perbaikan pertemuan berikutnya.

\section{Pertemuan ke-2, Siklus I}

\section{1) Tahap Perencanaan}

Pada tahap ini kegiatan yang dilakukan perbaikan RPP sesuai masukan saat refleksi pertemuan ke-1, menyiapkan lembar observasi guru, lembar observasi siswa, LKS, instrumen penilaian kuis, dll.

\section{2) Tahap Pelaksanaan}

Tahap ini dilaksanakan kegiatan pembelajaran, pada hari Selasa, tanggal 5 Maret 2019 jam ke- 3-4, dengan penjelasan sebagai berikut : pendahuluan (10 menit), kegiatan inti (70 menit) berupa proses pembelajaran dengan model Cooperative Learning tipe STAD yang dimulai dengan penjelasan materi pokok oleh guru, diskusi kelompok membahas materi sesuai kelompok masing- masing, dilanjutkan presentasi kelompok, diakhiri dengan penutup (10 menit) berupa kesimpulan dan diakhiri pemberian kuis.

\section{3) Tahap Observasi}

Pada tahap ini dilaksanakan saat kegiatan pembelajaran, berupa observasi terhadap kegiatan guru saat mengajar dan observasi terhadap aktivitas siswa belajar. Hasil observasinya sebagai berikut :

a) proses belajar siswa, diperoleh data bahwa 3 siswa tidak masuk, sehingga ada 23 siswa yang masuk, dan 2 diantaranya tidak aktif mengikuti proses belajar dalam kelompoknya, sehingga tingkat keaktifan siswa sebesar 91,3\%, tergolong bagus/ aktif.

b) Proses mengajar guru dengan menggunakan instrumen observasi, diperoleh skor 77, tergolong baik, namun ada sedikit kekurangan media pembelajaran yang digunakan guru kurang interaktif, hanya berupa rangkuman materi berupa power point. 
c) Hasil Belajar Siswa

Data penilaian kuis pada pertemuan ke- 1 , siklus I terjadi kenaikan poin rata- rata 11,95 , kelompok 4 memperoleh reward karena mencapai peningkatan poin tertinggi, seperti dipaparkan dalam tabel berikut.

Tabel 2. Peningkatan Poin Kelompok Pertemuan ke- 2, Siklus I

\begin{tabular}{cccc}
\hline Kelompok & $\begin{array}{c}\text { Nilai } \\
\text { awal }\end{array}$ & $\begin{array}{c}\text { Nilai } \\
\text { kuis }\end{array}$ & $\begin{array}{c}\text { Peningkatan } \\
\text { poin kelompok }\end{array}$ \\
\hline 1. & 57,5 & 87,5 & 30 \\
2. & 77,5 & 80 & 2,5 \\
3. & 82,5 & 85 & 2,5 \\
4. & 50 & 66,7 & 16,7 \\
5. & 70 & 80 & 10 \\
6. & 75 & 85 & 10 \\
\hline \multicolumn{2}{r}{ Rata- rata peningkatan poin } \\
\hline
\end{tabular}

4) Tahap Refleksi

Pada tahap ini dicermati kekurangan yang ada, untuk perbaikan pada pertemuan berikutnya.

\section{Pertemuan ke-3, Siklus I}

Pertemuan ke-3 digunakan sebagai penilaian harian siklus I. Dilaksanakan pada hari Selasa, 6 Maret 2019 jam 3- 4, ada 3 siswa tidak hadir, sehingga siswa yang mengikuti penilaian harian ada 23 anak, hasilnya sebagai berikut.

Tabel 3. Hasil Penilaian Harian Siklus I

\begin{tabular}{clc}
\hline No & \multicolumn{1}{c}{ Kriteria } & Jumlah Siswa \\
\hline 1. & Tuntas & 15 \\
2. & Tidak Tuntas & 8 \\
\hline & Prosentase Ketuntasan & $65,22 \%$ \\
\hline
\end{tabular}

\section{Hasil Penelitian Siklus II}

Siklus II terdiri dari 3 pertemuan, yaitu pertemuan ke-1 dan ke-2 merupakan kegiatan pembelajaran dan pertemuan ke-3 digunakan untuk penilaian harian.

\section{Pertemuan ke-1, Siklus II}

Kegiatan ini terdiri dari 4 tahap yaitu :

1) Tahap Perencanaan

Pada tahap ini kegiatan yang dilakukan perbaikan RPP sesuai masukan saat refleksi siklus I, menyiapkan lembar observasi guru, lembar observasi siswa, LKS, instrumen penilaian kuis, dll.

\section{2) Tahap Pelaksanaan}

Tahap ini dilaksanakan kegiatan pembelajaran, pada hari Selasa, tanggal 12 Maret 2019 jam ke- 3-4, dengan penjelasan sebagai berikut : pendahuluan (10 menit), kegiatan inti (70 menit) berupa proses pembelajaran dengan model Cooperative
Learning tipe STAD yang dimulai dengan penjelasan materi pokok oleh guru, diskusi kelompok membahas materi sesuai kelompok masing- masing, dilanjutkan presentasi kelompok, diakhiri dengan penutup (10 menit) berupa kesimpulan dan pemberian kuis.

3) Tahap Observasi

Pada tahap ini dilaksanakan saat kegiatan pembelajaran, berupa observasi terhadap kegiatan guru saat mengajar dan observasi terhadap aktivitas siswa belajar. Hasil observasinya sebagai berikut :

a) proses belajar siswa, diperoleh data bahwa 1 siswa tidak masuk, sehingga ada 25 siswa yang masuk, dan 1 diantaranya tidak aktif mengikuti proses belajar dalam kelompoknya, sehingga tingkat keaktifan siswa sebesar 96,00\%, tergolong bagus/ aktif.

b) Proses mengajar guru dengan menggunakan instrumen observasi, diperoleh skor 79, tergolong baik, guru melakukan moving untuk memantau proses diskusi kelompok, tujuannya agar siswa lebih aktif dalam proses belajar.

c) Hasil Belajar Siswa

Data penilaian kuis pada pertemuan ke- 1 , siklus I terjadi kenaikan poin rata- rata 8,27, kelompok 4 memperoleh reward karena mencapai peningkatan poin tertinggi, seperti dipaparkan dalam tabel berikut.

Tabel 4. Peningkatan Poin Kelompok Pertemuan ke- 1, Siklus II

\begin{tabular}{cccc}
\hline \multirow{2}{*}{ Kelompok } & $\begin{array}{c}\text { Nilai } \\
\text { awal }\end{array}$ & $\begin{array}{c}\text { Nilai } \\
\text { kuis }\end{array}$ & $\begin{array}{c}\text { Peningkatan } \\
\text { poin kelompok }\end{array}$ \\
\hline 1. & 87,5 & 87,5 & 0 \\
2. & 80 & 90 & 10 \\
3. & 85 & 87,5 & 2,5 \\
4. & 66,7 & 90 & 23,3 \\
5. & 80 & 86 & 6 \\
6. & 85 & 92,5 & 7,5 \\
\hline \multicolumn{4}{l}{ Rata- rata peningkatan poin } \\
\hline \multicolumn{4}{l}{}
\end{tabular}

4) Tahap Refleksi

Hasil refleksi antara lain : masih ada siswa yang kurang aktif dalam kegiatan pembelajaran, hal ini menjadi tantangan bagi guru untuk dapat mengelola kondisi yang negatif tersebut secara konstruktif, dengan terus memberikan motivasi kepada siswa tersebut agar dapat mencapai hasil belajar semaksimal mungkin.

\section{Pertemuan ke-2, Siklus II} berikut : 


\section{1) Tahap Perencanaan}

Pada tahap ini kegiatan yang dilakukan perbaikan RPP sesuai masukan saat refleksi siklus I, menyiapkan lembar observasi guru, lembar observasi siswa, LKS, instrumen penilaian kuis, dll.

\section{2) Tahap Pelaksanaan}

Tahap ini berupa kegiatan pembelajaran , yang dilaksanakan pada Rabu, tanggal 13 Maret 2019 jam ke 5-6, dengan penjelasan sebagai berikut : pendahuluan (10 menit), kegiatan inti (70 menit) berupa proses pembelajaran dengan model Cooperative Learning tipe STAD yang dimulai dengan penjelasan materi pokok oleh guru, diskusi kelompok membahas materi sesuai kelompok masing- masing, dilanjutkan presentasi kelompok, diakhiri dengan penutup (10 menit) berupa kesimpulan dan pemberian kuis.

\section{3) Tahap Observasi}

Obsevasi dilaksanakan saat kegiatan pembelajaran berlangsung, berupa observasi terhadap kegiatan guru saat mengajar dan observasi terhadap aktivitas siswa belajar. Hasil observasinya sebagai berikut :

a) proses belajar siswa, diperoleh data bahwa 5 siswa tidak masuk, sehingga ada 21 siswa yang masuk, dan 1 diantaranya tidak aktif mengikuti proses belajar dalam kelompoknya, sehingga tingkat keaktifan siswa sebesar 95,24\%, tergolong bagus/ aktif. Guru sudah melibatkan semua siswa dalam membuat kesimpulan dan refleksi.

b) Proses mengajar guru dengan menggunakan instrumen observasi, diperoleh skor 80, tergolong baik, guru melakukan moving untuk memantau proses diskusi kelompok, tujuannya agar siswa lebih aktif dalam proses belajar.

c) Hasil Belajar Siswa

Data penilaian kuis pada pertemuan ke- 2, siklus II terjadi kenaikan poin rata- rata 8,30, kelompok 3 memperoleh reward karena mencapai peningkatan poin tertinggi, seperti dipaparkan dalam tabel berikut.

Tabel 5. Peningkatan Poin Kelompok Pertemuan ke- 2, Siklus II

\begin{tabular}{cccc}
\hline Kelompok & $\begin{array}{c}\text { Nilai } \\
\text { awal }\end{array}$ & $\begin{array}{c}\text { Nilai } \\
\text { kuis }\end{array}$ & $\begin{array}{c}\text { ?eningkatan poin } \\
\text { kelompok }\end{array}$ \\
\hline 1. & 87,5 & 100 & 12,5 \\
2. & 90 & 95 & 5 \\
3. & 87,5 & 98,3 & 10,8 \\
4. & 90 & 90 & 0 \\
5. & 86 & 100 & 14 \\
6. & 92,5 & 100 & 7,5 \\
\hline \multicolumn{2}{l}{ Rata- rata peningkatan poin } & 8,30 \\
\hline
\end{tabular}

\section{4) Tahap Refleksi}

Hasil refleksi antara lain : masih ada siswa yang kurang aktif dalam kegiatan pembelajaran, hal ini merupakan hal yang sering terjadi dalam model pembelajaran kooperatif yang disebut dengan "free-rider effect" (efek "pendompleng") yaitu adanya murid tertentu yang kurang aktif dalam kegiatan pembelajaran dan membiarkan orang lain melakukan tugas pembelajaran, baik karena merasa tidak bisa atau tidak mau. Guru harus tertantang untuk dapat mengelola kondisi yang negatif tersebut secara konstruktif, agar hasil belajar dapat tercapai semaksimal mungkin.

\section{Pertemuan ke-3, Siklus II}

Pertemuan ke-3 digunakan sebagai penilaian harian siklus I. Dilaksanakan pada hari Selasa, 19 Maret 2019 jam 3- 4, seluruh siswa hadir, sehingga siswa yang mengikuti penilaian harian ada 26 anak, hasilnya sebagai berikut.

Tabel 6. Hasil Penilaian Harian Siklus II

\begin{tabular}{clc}
\hline No & \multicolumn{1}{c}{ Kriteria } & Jumlah Siswa \\
\hline 1. & Tuntas & 20 \\
2. & Tidak Tuntas & 6 \\
\hline & Prosentase Ketuntasan & $76,92 \%$ \\
\hline
\end{tabular}

\section{PEMBAHASAN}

\section{Penerapan Model Cooperative Learning Tipe $S T A D$ pada Pembelajaran Geografi Kelas XI IPS 3 SMA N 1 Banguntapan, Bantul Tahun Ajaran 2018/ 2019 \\ STAD (Student Team Achievment} Divission) merupakan model pembelajaran yang diterapkan untuk mengatasi rendahnya proses belajar dan hasil belajar siswa kelas XI IPS 3 SMA N 1 Banguntapan, Bantul Tahun Ajaran 2018/ 2019, dimana siswa dibagi dalam kelompok secara heterogen sehingga anak yang berbada gender, agama, kemampuan akademik, dll dimungkinkan ada dalam suatu kelompok. Perbedaan akademik justru dikelola secara positif. Siswa dengan kemampuan akademik tinggi dapat menjadi tutor teman sebaya bagi anak dengan kemampuan akademik sedang dan rendah. Dalam proses pembelajaran guru menjelaskan materi pokok, kemudian masing- masing kelompok diberikan materi untuk dibahas secara kelompok, selanjutnya hasil diskusi kelompok dipresentasikan. Pada akhir pembelajaran diberikan penilaian berupa kuis yang dikerjakan secara individu, tetapi 
perolehan nilainya dikumpulkan menjadi nilai/ poin kelompok. Model pembelajaran ini menimbulkan sikap positif antara lain : a) siswa lebih aktif dalam proses pembelajaran karena secara berkelompok melakukan diskusi untuk membahas materi yang diberikan guru, b) menumbuhkan interaksi yang lebih intens antara siswa dengan siswa dan siswa dengan guru, c) meningkatkan kemampuan berkomunikasi saat mempresentasikan hasil diskusi kelompok, d) adanya tanggung jawab individu yang lebih karena keberhasilan mendapatkan poin kelompok ditentukan oleh perolehan poin dari masing- masing individu.

\section{Proses Mengajar Guru.}

Model Pembelajaran aktif tipe STAD meningkatkan kemampuan guru dalam pembelajaran, seperti pembuatan media pembelajaran, penyususnan Lembar Kerja Siswa, penyusunan instrumen penilaian, meningkatkan kemampuan pengelolaan kelas, dll. Skor kemampuan guru mengajar meningkat dari siklus I sebesar 76, menjadi 79,5 ke siklus II seperti tertera pada tabel berikut.

Tabel 7. Peningkatan Skor Kemampuan

\begin{tabular}{cccc}
\multicolumn{4}{c}{ Mengajar Guru } \\
\hline \multirow{2}{*}{ Jumlah skor observasi guru } & \multicolumn{2}{c}{ Skor rata- rata } \\
\hline \multirow{2}{*}{ Siklus I } & Pertemuan 1 & 75 & \multirow{2}{*}{76} \\
& Pertemuan 2 & 77 & \\
\hline \multirow{2}{*}{ Siklus II } & Pertemuan 1 & 79 & \multirow{2}{*}{79,5} \\
& Pertemuan 2 & 80 & \\
\hline
\end{tabular}

\section{Proses Belajar Siswa.}

Model Pembelajaran aktif tipe STAD meningkatkan peran aktif siswa dalam proses pembelajaran.

Tabel 8. Keaktivan Proses Belajar Siswa

\begin{tabular}{ccccccc}
\hline Siklus & Pert & $\begin{array}{c}\text { Siswa } \\
\text { absen }\end{array}$ & $\begin{array}{c}\text { Siswa } \\
\text { Hadir }\end{array}$ & $\begin{array}{c}\text { Siswa } \\
\text { tidak } \\
\text { aktif }\end{array}$ & $\begin{array}{c}\text { Siswa } \\
\text { aktif }\end{array}$ & $\begin{array}{c}\text { Tingkat } \\
\text { Keaktifan } \\
\text { proses belajar }\end{array}$ \\
\hline I & 1 & 3 & 23 & 2 & 21 & $91,30 \%$ \\
\cline { 2 - 7 } & 2 & 3 & 23 & 2 & 21 & $91,30 \%$ \\
\hline \multicolumn{2}{l}{ Rata- rata keaktifan } & & & & $\mathbf{9 1 , 3 0 \%}$ \\
\hline II & 1 & 1 & 25 & 1 & 24 & $96,00 \%$ \\
\cline { 2 - 7 } & 2 & 5 & 21 & 1 & 20 & $95,24 \%$ \\
\hline
\end{tabular}

Pada siklus I aktivitas siswa sebesar 91,30\% tergolong aktif/ bagus dan siklus II sebesar 95,62\% tergolong aktif/ bagus.

\section{Hasil Belajar}

Penerapan Model Pembelajaran aktif tipe $S T A D$ dapat meningkatkan hasil belajar siswa, baik hasil penilaian kuis maupun penilaian harian, seperti tertera pada tabel berikut.
Tabel 9. Hasil Penilaian Kuis

\begin{tabular}{|c|c|c|c|c|c|c|c|c|c|}
\hline \multirow{2}{*}{ Siklus } & \multirow{2}{*}{ Pertemuan } & \multicolumn{6}{|c|}{ Peningkatan Poin Kelompok } & \multirow{2}{*}{$\begin{array}{c}\text { Rata- } \\
\text { rata per } \\
\text { pertem } \\
\text { uan }\end{array}$} & \multirow{2}{*}{$\begin{array}{c}\text { Rata- } \\
\text { rata per } \\
\text { siklus }\end{array}$} \\
\hline & & 1 & 2 & 3 & 4 & 5 & 6 & & \\
\hline \multirow{2}{*}{ I } & 1 & $-16,75$ & 7,9 & 14,5 & -19 & 2,8 & 7 & $-0,59$ & \multirow{2}{*}{5,68} \\
\hline & 2 & 30 & 2,5 & 2,5 & 16,7 & 10 & 10 & 11,95 & \\
\hline \multirow{2}{*}{ II } & 1 & 0 & 10 & 2,5 & 23,3 & 6 & 7,5 & 8,27 & \multirow{2}{*}{8,29} \\
\hline & 2 & 12,5 & 5 & 10,8 & 0 & 14 & 7,5 & 8,30 & \\
\hline
\end{tabular}

Hasil penilaian kuis terjadi peningkatan dari siklus I sebesar 5,68 poin menjadi 8,29 poin pada siklus II. Sedangkan hasil penilaian harian juga mengalami peningkatan tingkat ketuntasan belajar dari $15,38 \%$ pada pra siklus, menjadi $65,22 \%$ pada siklus I dan $76,92 \%$ pada siklus II seperti tertera pada tabel berikut.

Tabel 10. Hasil Penilaian Harian

\begin{tabular}{ccccc}
\hline No & Kriteria & $\begin{array}{c}\text { Pra Siklus } \\
\text { (nilai UAS sem. 3) }\end{array}$ & Siklus I & Siklus II \\
\hline 1. & Tuntas & 4 & 15 & 20 \\
\hline 2. & Tidak Tuntas & 22 & 8 & 6 \\
\hline & $\begin{array}{l}\text { Prosentase } \\
\text { ketuntasan }\end{array}$ & $15,38 \%$ & $65,22 \%$ & $76,92 \%$ \\
\hline
\end{tabular}

\section{KESIMPULAN}

Pelaksanaan Penelitian Tindakan Kelas dengan model pembelajaran kooperatif tipe STAD (Student Teams- Achievement Devision) pada pelajaran geografi di kelas XI IPS 3 SMA Negeri 1 Banguntapan Tahun Ajaran 2018/ 2019 menghasilkan kesimpulan sebagai berikut:

1. Penerapan Model Pembelajaran Kooperatif Tipe STAD (Student Teams Achievement Devision) sebagai upaya meningkatkan proses dan hasil belajar geografi pada siswa kelas XI IPS 3 SMA Negeri 1 Banguntapan Tahun Ajaran 2018/ 2019 dilakukan dengan membagi siswa kedalam 6 kelompok belajar secara heterogen. Proses belajar meliputi menggali informasi terkait materi ajar melalui diskusi kelompok dilanjutkan presentasi hasil diskusi kelompok, dan penilaian kuis pada akhir pembelajaran. Perolehan skor/ nilai kuis dibandingkan dengan skor penilaian sebelumnya untuk mengetahui peningkatan poin. Poin individu digabung menjadi poin kelompok, sehingga masing- masing anggota kelompok harus berkontribusi maksimal untuk meraih sukses kelompok, hal ini akan menumbuhkan motivasi belajar yang berperan penting bagi perolehan hasil belajar yang maksimal. 
2. Model pembelajaraan kooperatif tipe STAD mampu meningkatkan proses belajar geografi siswa kelas XI IPS 3 SMA Negeri 1 Banguntapan Tahun Ajaran 2018/ 2019 berdasarkan peningkatan tingkat keaktifan belajar siswa dari siklus I sebesar 91,3\% menjadi 95,62 \% pada ke siklus II, keduanya tergolong tingkat partisipasi yang bagus.

3. Model pembelajaraan kooperatif tipe STAD mampu meningkatkan hasil belajar geografi siswa kelas XI IPS 3 SMA Negeri 1 Banguntapan Tahun Ajaran 2018/ 2019 berdasarkan peningkatan poin hasil penilaian kuis dari siklus I sebesar 5,68 poin menjadi 8,27 poin pada siklus II. Disamping itu terjadi peningkatan ketuntasan belajar dari siklus I sebesar dari $15,38 \%$ pada pra siklus, menjadi $65,22 \%$ pada siklus I dan $76,92 \%$

\section{DAFTAR PUSTAKA}

Andriantari, Jamaliah. (2010). Upaya Meningkatkan Minat dan Prestasi Belajar IPS Melalui Cooperative Learning Tipe STAD Pada Siswa Kelas V SD Negeri Pengenjuru Tengah Purworejo Tahun 2008/ 2009. Universitas PGRI Yogyakarta. Tesis

Bahri, Syaiful. (2006). Strategi Belajar Mengajar .Jakarta : Rineka Cipta

Daniel Muijs \& David Reynolds. (2008). Effective Teaching Teori dan Aplikasi. Edisi kedua. Yogyakarta: Pustaka Pelajar. Terjemahan

Haryati, Mimin. (2008). Model dan teknik Penilaian Pada Tingkat Satuan Pendidikan. Jakarta : Gaung Persada Press
Rickey, W.R. 1973. Planing for Teaching An Introduction To Eddition. Fifth Education. New York : McGraw- Hill Book Company

Saidiharjo. (1994). Pengembangan Kurikulum Ilmu Pengetahuan Sosial. Modul. Yogyakarta: Program Pasca Sarjana UPY

Silabus Mata Pelajaran Geografi SMA. (2013)

Slavin, Robert E. (1994). Cooperative Learning Theory, Research, and Practice. Terjemahan. Bandung : Nusa Media

Soewandi, Slamet dkk. (2005). Perspektif Pembelajaran Bebagai Bidang Study. Kumpulan Hasil Penilaian . Yogyakarta : Universitas Sanatadarma.

Usman, Uzer dan Lilis Setiawati. (1993). Upaya Optimalisasi Belajar Mengajar. Bandung : Rosda Karya

Wasisto, Agus. (2018). Cara Mudah Melakukan Penelitian Tindakan Kelas. Yogyakarta: Graha Cendikia

Widarwati. (2009). Strategi dan Metode Pembelajaran. Makalah disampaikan pada Pendidikan dan Pelatihan Guru Geografi SMA Jenjang Dasar. Malang: Pusat Pengembangan dan Pemberdayaan Pendidik dan Tenaga Kependidikan.

Widarwati. 2009. Pengembangan Sistem Penilaian. Makalah disampaikan pada Pendidikan dan Pelatihan Guru Geografi SMA Jenjang Dasar. Malang: Pusat Pengembangan dan Pemberdayaan Pendidik dan Tenaga Kependidikan 